\title{
Synthesis of RNA during Myxospore Induction in Myxococcus xanthus
}

\author{
By H. A. FOSTER AND J. H. PARISH \\ Department of Biochemistry, University of Leeds, \\ 9 Hyde Terrace, Leeds, LS2 $9 L S$
}

(Received 6 October 1972)

\begin{abstract}
SUMMARY
RNA was isolated from vegetative Myxococcus xanthus FB and myxospores. Organisms were labelled with $\left[{ }^{32} \mathrm{P}\right]$ orthophosphate during encystment and the metabolic stability of the radioactive RNA was followed by fractionating purified RNA from 'pulse-chased' cultures by polyacrylamide gel electrophoresis. Much of the label was in heterodisperse (messenger-like) RNA but the stable RNA (present in the mature myxospores) was largely high-molecular weight ribosomal RNA and its precursors.

The role of RNA synthesis in the morphogenetic cycle of Myxococcus xanthus is discussed in the light of these data and of the properties of the ribosomes and ribosomal proteins from this organism.
\end{abstract}

\section{INTRODUCTION}

The stages involved in the induction of myxospore production in Myxococcus xanthus are summarized in Fig. I. The short period of DNA synthesis has been studied by Rosenberg, Katarski \& Gottlieb (1967) who concluded that the synthesis corresponded to replication of $20 \%$ of the total chromosomes present in the population and that no chromosome division was reinitiated in this period. The nature of the RNA synthesized during the early phases of myxospore induction has been characterized by fractionating the RNA (Bacon \& Rosenberg, 1967) and by using RNA:DNA hybridization (Okano, Bacon \& Rosenberg, 1972). They concluded that both rRNA (ribosomal RNA) and heterodisperse mRNA (messenger RNA) of lower sedimentation coefficients than I6 S rRNA are synthesized during this period, and that although the rRNA is indistinguishable from that present in vegetatively growing organisms, certain species of mRNA synthesized during myxospore induction are not synthesized during vegetative growth. Conversely, certain species of mRNA synthesized during vegetative growth are absent from organisms undergoing myxospore induction.

At an advanced stage of the process (after refractility had been achieved; see Fig. I) there is another burst of RNA synthesis (Ramsay \& Dworkin, I970). We refer to this as ' 4 to $5 \mathrm{~h}$ RNA'. Ramsay \& Dworkin (1970) isolated this RNA by breaking the organisms with glass beads in a mechanical shaker and fractionated it by sucrose-gradient centrifugation. They compared pulse-labelled RNA with RNA that had been pulsed and 'chased' with actinomycin D. We have extended this study by using different methods for isolating the RNA and fractionation by polyacrylamide-gel electrophoresis. In this paper we compare ${ }^{32} \mathrm{P}$-pulselabelled 4 to $5 \mathrm{~h}$ RNA with RNA pulse-labelled and 'chased' into mature myxospores in the presence of unlabelled phosphate. 


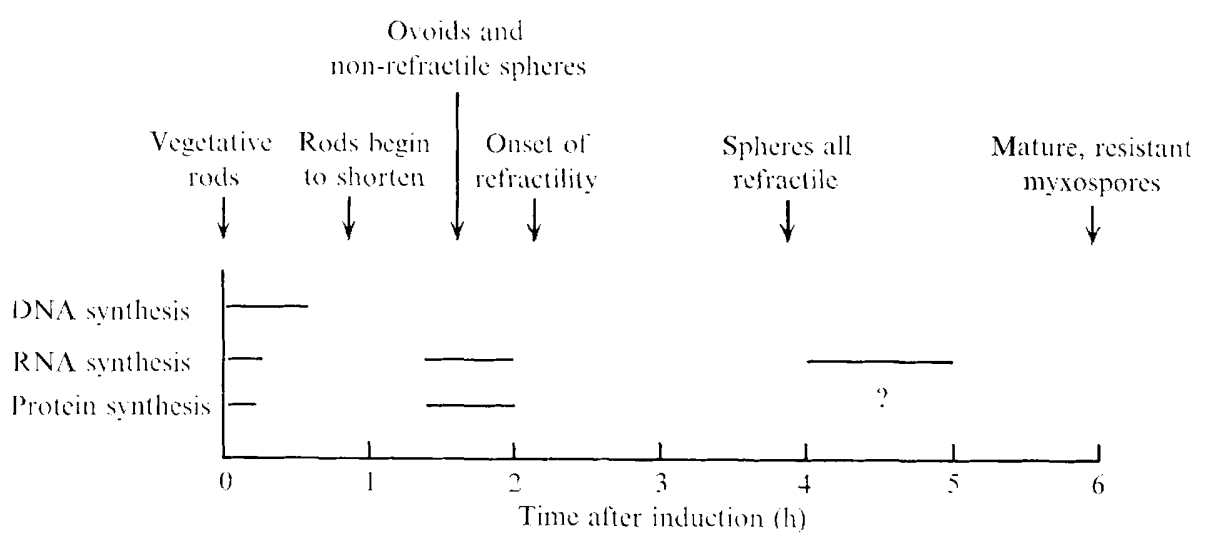

Fig. I. Stages of myxospore induction in Myxococcus xanthus in liquid medium, based on the data of Sadler \& Dworkin (1966) and Ramsay \& Dworkin (1970).

\section{METHODS}

Sources of chemicals were as described by Foster \& Parish (1973). Polyvinyl sulphate was obtained from Sigma Chemical Co., St Louis, Missouri, U.S.A., sodium triisopropylnaphthalene sulphonate from Kodak Ltd, Kirkby, Liverpool, precipitated acid-washed silica from $\mathrm{BDH}$, Poole, Dorset and DEAE-cellulose (Whatman, DE23) from H. Reeve Angel Ltd, London.

Myxococcus xanthus $\mathrm{FB}$ was grown in shaken cultures of $25 \mathrm{ml}$ in $250 \mathrm{ml}$ conical flasks at $30^{\circ} \mathrm{C}$ in an orbital incubator $(300 \mathrm{rev} . / \mathrm{min}$.) in deionized casitone medium (Foster \& Parish, 1973).

Bacillus sp. no. 4 (apparently a strain of $B$. licheniformis) a gift from Professor M. Dworkin, Department of Microbiology, University of Minnesota, secretes into the medium an enzyme (or other factors) which lyses heat-killed or freeze-thawed myxospores.

Labelling methods. Vegetative organisms were labelled by adding [32P]orthophosphate (60 Ci/mg P; I Ci $/ 25 \mathrm{ml}$ culture). After $5 \mathrm{~min}$, chloramphenicol ( $\mathrm{I} \mathrm{mg} / \mathrm{ml}$ ) and sodium azide (to $1 \mathrm{mM}$ ) were added and the cells were poured on to crushed ice and harvested. Myxospore formation was induced in $25 \mathrm{ml}$ cultures by adding glycerol (Bacon \& Rosenberg, I967) and after $4.5 \mathrm{~h},\left[{ }^{32} \mathrm{P}\right]$ orthophosphate was added as above. After I $5 \mathrm{~min}$ phosphate buffer was added to Io mM. In some experiments the bacteria were poured onto crushed ice and harvested and washed with phosphate buffer as above; in others, the cultures were returned to the orbital shaker and harvested after a further $2 \mathrm{~h}$. We confirmed that the cysts were mature, resistant, refractile spheres by observing them under the phase-contrast microscope and establishing that they were unchanged in appearance and were also viable after sonication. They are referred to as 'pulse-chased myxospores'. They were normally harvested as described by Foster \& Parish (1973); for certain experiments they were harvested and washed aseptically and returned to fresh casitone medium containing $10 \mathrm{~mm}$ potassium phosphate buffer; these organisms were then harvested after $15 \mathrm{~min}$ at $30{ }^{\circ} \mathrm{C}$.

Isolation of RNA. RNA was isolated from vegetative organisms by a modification (Parish, 1968) of the method of Kirby, Fox-Carter \& Guest (I967). The preparations contained all the RNA species present in the organisms and some of the DNA. RNA was isolated from myxospores by several methods which are summarized below.

Freeze-thawed methods. The myxospores were freeze-thawed by immersion successively 
in solid $\mathrm{CO}_{2}$ /ethanol and water $\left(30^{\circ} \mathrm{C}\right)$ Io times. In the 'urea method' the freeze-thawed cells were treated with $8 \mathrm{M}$-urea, 10\% (v/v) 2-mercaptoethanol (Sakakibara, Tanooka \& Terano, 1970), then extracted by the method of Kirby et al. (1967). In the 'freeze-thawed/ phenol method' the freeze-thawing was performed in the presence of the deproteinizing mixture used by Kirby et al. (1967).

Bacillus sp. no. 4 enzymes. The following procedure is that of D. S. Weisberg \& M. Dworkin (personal communication). The Bacillus strain was grown in $\mathrm{I} \%$ (w/v) Bacto-casitone, Io mM-potassium phosphate buffer, $\mathrm{pH} 7 \cdot 4$, to an absorbance of $2 \cdot 0$ at $540 \mathrm{~nm}$. The bacteria were removed by centrifugation and the supernatant dialysed against solid polyethylene glycol 6000 at $4{ }^{\circ} \mathrm{C}$ to reduce the volume to 0.2 vol. It was then dialysed against $0 \cdot \mathrm{I}$ M-potassium phosphate buffer, $\mathrm{pH} 7.5$ for a total of $2 \mathrm{I} h$ with one change of buffer. Two volumes of cold acetone $\left(-10{ }^{\circ} \mathrm{C}\right)$ were added slowly. The precipitate was removed by centrifugation, dissolved in $\mathrm{IO} \mathrm{mm}$-tris $\mathrm{HCl} \mathrm{pH} \mathrm{7*4}(20 \mathrm{ml})$ and dialysed against the same buffer. For lysis of myxospores (or assay of the preparation) the following components were incubated for $20 \mathrm{~min}$ at $37^{\circ} \mathrm{C}$ : myxospores in $\mathrm{I} \mathrm{mg} / \mathrm{ml}$ chloramphenicol solution (freeze-thawed four times; I.60 ml), 0.I M-potassium phosphate buffer, pH $7.5(0.04 \mathrm{ml})$, I $\mathrm{mg} / \mathrm{ml}$ chloramphenicol $(0.64 \mathrm{ml})$, water, $(0.77 \mathrm{ml})$, I $\mathrm{M}-\mathrm{MgCl}_{2}(0.20 \mathrm{ml})$, Bacillus sp. no. 4 preparation $(0.05 \mathrm{ml}), 10 \%(\mathrm{w} / \mathrm{v})$ sodium cholate $(0.30 \mathrm{ml}), 0.4 \mathrm{mg} / \mathrm{ml}$ polyvinyl sulphate $(0.2 \mathrm{ml})$. The drop in $E_{540 \mathrm{~nm}}$ was measured. For isolation of RNA, the suspension was extracted by the method of Kirby et al. (1967). Ribonuclease was assayed by 'Method I' of Uchida \& Egami (1967). In one experiment, the preparation of Bacillus 'enzyme' was fractionated by column chromatography. A sample containing I $\mathrm{mg}$ protein was applied to a column ( $\mathrm{I} 0 \mathrm{~cm} \times \mathrm{I} \mathrm{cm}$ ) of DEAE-cellulose, equilibrated in $0.0 \mathrm{I} \mathrm{M}$-tris $\mathrm{HCl}, \mathrm{pH} 7 \cdot 4$, and eluted with a linear gradient of o to I $\mathrm{M}-\mathrm{NaCl}$ (in the same buffer). The absorbance at $280 \mathrm{~nm}$ of the eluate was monitored and fractions were assayed for ribonuclease and myxospore lytic activity.

Silica and alumina grinding methods. The deproteinization procedure is essentially that of Parish \& Kirby (1966). 'Phenol mixture' is made by liquefying phenol (500 g) by addition of $m$-cresol ( $70 \mathrm{ml})$, water $(55 \mathrm{ml})$ and 8 -hydroxyquinoline $(0.5 \mathrm{~g})$. Washed vegetative organisms or myxospores were suspended in $6 \%(\mathrm{w} / \mathrm{v})$ sodium 4-aminosalicylate, $\mathrm{I} \%(\mathrm{w} / \mathrm{v}) \mathrm{NaCl}$, $\mathrm{I} \%(\mathrm{w} / \mathrm{v})$ sodium triisopropylnaphthalene sulphonate, 2 mM-ethylenediamine tetracetic acid disodium salt, $3 \%(\mathrm{v} / \mathrm{v})$ phenol mixture ('solution $\mathrm{A}$ '; $2 \mathrm{ml}$ ). The suspension was transferred to a mortar and over a period of $15 \mathrm{~min}$ at $0{ }^{\circ} \mathrm{C}$ silica or alumina was added in small amounts and ground with a pestle until the material formed a stiff paste. The paste was extracted with $\mathrm{I} 0 \mathrm{ml}$ solution $\mathrm{A}$ and $\mathrm{I} 0 \mathrm{ml}$ phenol mixture at room temperature for $20 \mathrm{~min}$, the phases were separated by centrifugation at $4{ }^{\circ} \mathrm{C}$ and the upper phase removed with a Pasteur pipette. Solid $\mathrm{NaCl}(2 \%, w / v)$ was dissolved in this phase which was then extracted with $0.5 \mathrm{vol}$. phenol mixture for $10 \mathrm{~min}$ at room temperature. The phases were separated as before and the upper phase added to 2 vol. ethanol at $-20{ }^{\circ} \mathrm{C}$. The precipitate (nucleic acid) was removed by centrifugation, washed twice with $2 \%(\mathrm{w} / \mathrm{v}) \mathrm{NaOAc} .3 \mathrm{H}_{2} \mathrm{O}$ in $75 \%(\mathrm{v} / \mathrm{v})$ aqueous ethanol and dissolved in electrophoresis buffer at $4{ }^{\circ} \mathrm{C}$. Any insoluble material (mucopolysaccharide) was removed by centrifugation.

Fractionation of RNA. RNA was fractionated by polyacrylamide-gel electrophoresis according to the procedures of Loening ( I968) with the minor modification described by Parish, Khairul Bashar, Brown \& Brown (I97I). Details of running conditions are described in the legends to Figures and Loening (I968). Gels were stained and destained (Parish et al. I97I) and scanned in the Joyce-Loebl Chromoscan using the 5-045 orange filter. The gels were frozen, sliced into $\mathrm{I} \mathrm{mm}$ slices and counted in water (Cherenkov radiation) in a Beckman liquid scintillation spectrophotometer to a standard error of $2 \%$. 

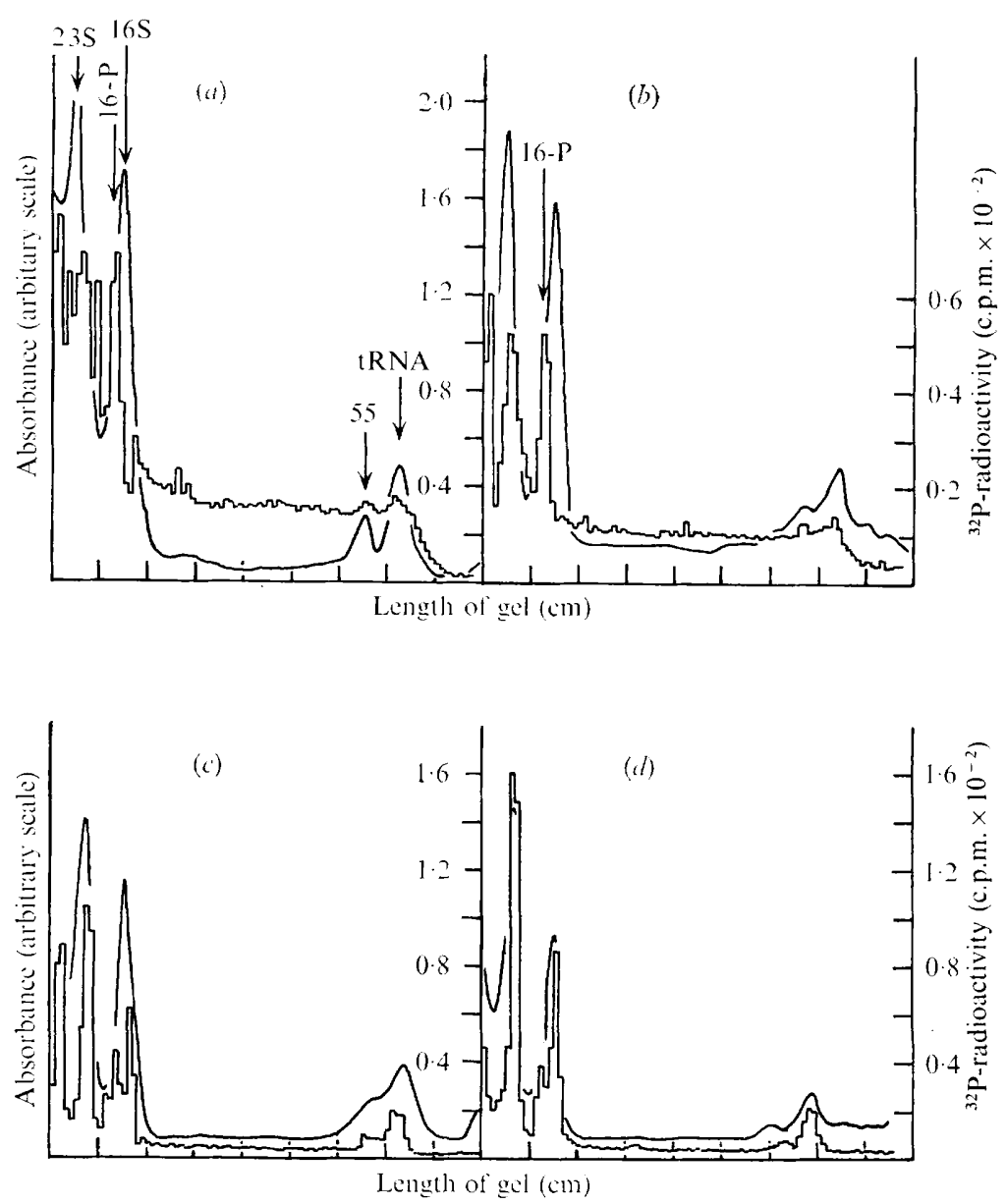

Fig. 2. Fractionation of labelled RNA by electrophoresis on $3.3 \%$ polyacrylamide gels. Details of labelling methods and preparation and fractionation of RNA are described in Methods. Continuous lines are stained nucleic acid; histograms ${ }^{32} \mathrm{P}$-radioactivity.

(a) Pulse-labelled vegetative organisms; (b) pulse-labelled 4 to $5 \mathrm{~h}$ RNA in organisms undergoing myxospore induction; $(c)$ pulse-chased RNA from mature myxospores; $(d)$ RNA from myxospores (as in $c$ ) germinated for $15 \mathrm{~min}$.

Table r. Evaluation of methods for isolating RNA from Myxococcus xanthus myxospores

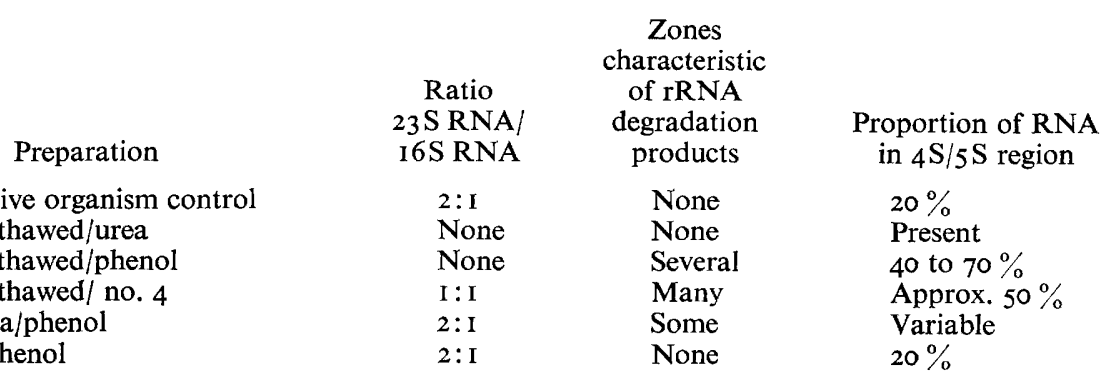

Vegetative organism control

Freeze-thawed/urea

Freeze-thawed/phenol

Freeze-thawed/ no. 4

Alumina/phenol

Silica/phenol
Proportion of RNA

$20 \%$

Present

Approx. $50 \%$

$20 \%$ 

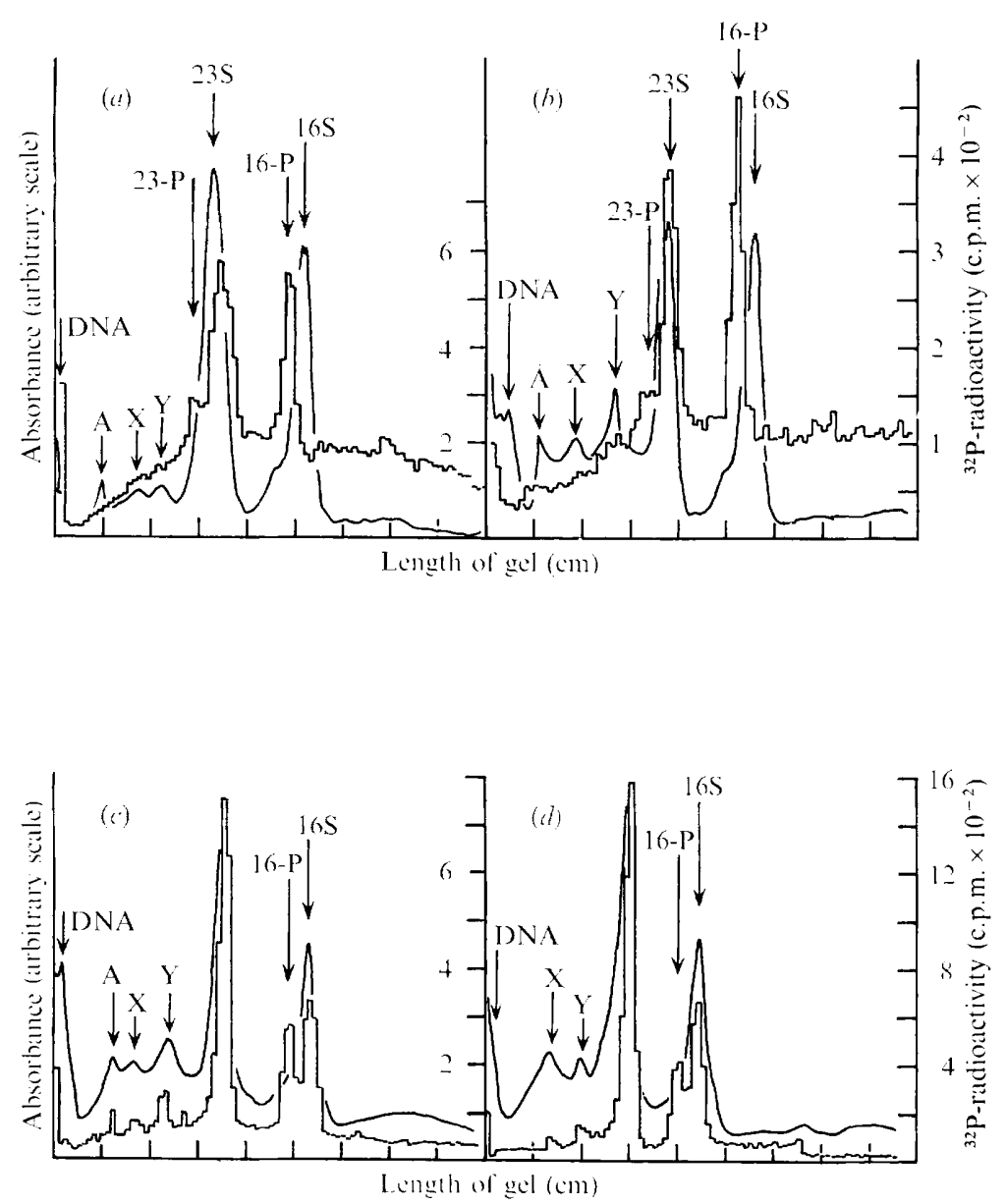

Fig. 3. Fractionation of labelled RNA by electrophoresis on $2 \cdot 6 \%$ polyacrylamide gels. Continuous lines are stained nucleic acid. Zone $\mathrm{A}$ is an artefact (not blue stain) presumed to be due to mucopolysaccharide. Histograms are ${ }^{32} \mathrm{P}-$ radioactivity.

(a) Pulse-labelled vegetative organisms; (b) pulse-labelled 4 to $5 \mathrm{~h}$ RNA in organisms undergoing myxospore induction; $(c)$ pulse-chased RNA from mature myxospores; $(d)$ RNA from myxospores (as in c) germinated for 15 min.

\section{RESULTS}

Isolation of RNA from myxospores. Unlabelled RNA isolated from myxospores by a variety of procedures and analysed by electrophoresis in $3.3 \%$ polyacrylamide gels was compared with the total RNA isolated from vegetative cells (Table I). In the methods using freeze-thawed bacteria, low-molecular weight RNA is preferentially extracted; Bacillus sp. no 4 'enzyme' is potentially useful for lysing myxospores and releasing high-molecular weight RNA, but we were unable to prevent some degradation of the RNA. This degradation may occur during the freeze-thawing. Preparations of this 'enzyme' contain roo to 200 units/ml of ribonuclease and it is unlikely that any ribonuclease inhibitor will totally protect RNA. Fractionation of the Bacillus sp. no. 4 preparation by ion-exchange chromotography of DEAE-cellulose yielded several peaks of protein. Ribonuclease is eluted between $0 \cdot \mathrm{I}$ and $\mathrm{O} \cdot \mathrm{I} 5 \mathrm{M}-\mathrm{NaCl}$. We were unable to detect any myxospore lytic activity in fractions 
of eluate. The observed lytic activity may be due to a combination of two or more enzyme activities.

Attempts at grinding the myxospores with alumina in the presence of the deproteinizing mixture gave variable yields of nucleic acid. Poor recoveries of RNA were obtained when very small amounts of material (as are used for experiments on radioactively labelled myxospores) were employed, perhaps due to binding of nucleic acids to basic sites in the alumina. Acid-washed silica powder was examined as a possible alternative grinding material. We have consistently obtained reproducible yields of undegraded RNA using this technique.

Fractionation of labelled RNA. The results of fractionating RNA on $3.3 \%$ and $2.6 \%$ gels are summarized respectively in Fig. 2 and 3.

Heterodisperse RNA (possibly mRNA) migrating between the $16 \mathrm{~S}$ and $5 \mathrm{~S}$ zones is present in pulse-labelled RNA from vegetative organisms and those undergoing morphogenesis (Fig. $2 a, 2 b, 3 a, 3 b$ ). This material has largely been eliminated in the mature myxospores (Fig. $2 c, 3 c$ ). Transfer RNA and $5 \mathrm{~S}$ rRNA synthesized during the 4 to $5 \mathrm{~h}$ period (Fig. $2 b$ ) are present in the mature myxospores (Fig. $2 c$ ).

In both types of pulse-labelled organisms $23 \mathrm{~S}$ rRNA is labelled. There is radioactivity in zones (I6-P and 23-P) characteristic of rRNA precursors (Fig. $3 a, b$; Hecht \& Woese, I968). In the mature myxospores, no 23-P RNA is present but only a proportion of the I6-P RNA has been converted to I6 S rRNA (Fig. $3 c$ ). This proportion is increased during the first I 5 min of germination; there are no other substantial changes in the labelled RNA during this period (Figs. $2 d$ and $3 d$ ). We have neglected any changes in the zones $\mathrm{X}$ and $\mathrm{Y}$ (Fig. 3 ) as these are probably aggregates of rRNA (Parish, 1972).

\section{DISCUSSION}

The burst of RNA synthesis late in myxospore induction is possibly analogous to the RNA that is synthesized late in the division cycle during vegetative growth. Myxococcus xanthus has a DNA synthetic phase corresponding to 0.8 of the growth cycle (Zusman \& Rosenberg, I970); there is synthe sis of both 'stable' (rRNA and tRNA) and ' unstable' RNA synthesis in the period between the end of the DNA synthetic phase and the physical separation of the organisms (Zusman \& Rosenberg, 197I), even though the rate of protein synthesis increases linearly throughout the cycle (Zusman, Gottlieb \& Rosenberg, I97I).

Our data imply that 4 to $5 \mathrm{~h}$ RNA contains all classes of RNA but that the 'stable' RNA in the mature myxospores is tRNA (transfer RNA) rRNA and rRNA precursors. The turnover of rRNA correlates with evidence that at least the $30 \mathrm{~S}$ ribosomal subunit is different in the myxospores (Foster \& Parish, I973). We believe that demonstration of high-molecular weight RNA synthesis in myxospores requires disruption of the cells (by silica grinding) in the presence of potent nuclease inhibitors (phenol and triisopropylnaphthalene sulphonate) and accounts for the failure of Ramsay $\&$ Dworkin (1970) to observe this material. In experiments (not reported in detail here) in which labelled RNA was extracted by the 'Bacillus sp. no. 4 method', we were unable to obtain any ribosomal precursor RNA. We have no evidence that heterodisperse RNA (characteristic of mRNA) synthesized during the 4 to $5 \mathrm{~h}$ period is present in the mature myxospores. The question of whether stable mRNA is present in myxospores remains open. As actinomycin D failed to inhibit germination, Ramsay \& Dworkin (1968) concluded that stable mRNA was present in the myxospores. This conclusion may need to be re-evaluated in the light of the selective inhibition of certain, but not all, classes of RNA by the concentration of the antibiotic involved (M. Dworkin, personal communication). The type of transcriptional control effected by a modification to the 
$\sigma$-factor postulated in sporulation in Bacillus subtilis (Losick \& Sonenshein, 1969) is probably not involved during myxospore induction (Okano et al. 1972). Our studies (Foster \& Parish, I973) imply that translational control operates in myxospores. The present paper suggests that RNA synthesis required for the assembly of myxospore ribosomes occurs during the 4 to $5 \mathrm{~h}$ period.

We are grateful to Miss M. Brown for excellent technical assistance, and to Professor M. Dworkin for the gift of bacteria, access to results prior to publication, and for discussion. H. A. F. was holder of a Science Research Council Studentship and the work was additionally supported by a Research Grant (to J.H.P.) from the S.R.C.

\section{REFERENCES}

Bacon, K. \& Rosenberg, E. (1967). Ribonucleic acid synthesis during morphogenesis in Myxococcus xanthus. Journal of Bacteriology 94, I 883-I 889.

Foster, H. A. \& PARISH, J. H. (1973). Ribosomes, ribosomal subunits and ribosomal proteins from $M y x o-$ coccus xanthus. Journal of General Microbiology, 75, 39I-400.

Hecht, N. B. \& Woese, C. R. (1968). Separation of bacterial ribosomal ribonucleic acid from its macromolecular precursors by polyacrylamide gel electrophoresis. Journal of Bacteriology 95, 986-990.

Kirby, K. S., FoX-CARTER, E. \& GUEST, M. (1967). Isolation of deoxyribonucleic acid and ribosomal ribonucleic acid from bacteria. Biochemical Journal ro4, 258-262.

LoENING, U. E. (1968). The fractionation of high molecular weight RNA. In Chromatographic and Electrophoretic Techniques. Zone Electrophoresis vol. 2, pp. 437-442. Edited by I. Smith. London: Heinemann.

Losick, R. \& SonEnsheIN, A. L. (I969). Change in the template specificity of RNA polymerase during sporulation in Bacillus subtilis. Nature, London, 224, 35-38.

OKAno, P., BACON, K. \& Rosenberg, E. (1972). Ribonucleic acid synthesis during microcyst formation in Myxococcus xanthus: Characterization by deoxyribonucleic acid-ribonucleic acid hybridization. Journal of Bacteriology 104, 275-282.

PARISH, J. H. (1968). Use of DEAE-cellulose for the chromatography of RNA of high molecular weight. Biochimica et biophysica acta $\mathbf{1 6 9}$, I4-20.

PARISH, J. H. (1972). Isolation and fractionation of RNA. In Subcellular Components, 2nd ed. pp. 25 I-278. Edited by G. D. Birnie. London: Butterworths.

Parish, J. H., Khairul Bashar, S. A. M., Brown, N. L. \& Brown, M. (197 I). Cell-free synthesis of tryptophanase from Escherichia coli. Use of ribonucleic acid isolated from induced cells and a comparison of the product from a system employing ribosomes and exogenous ribonucleic acid. Biochemical Journal I25, 643-653.

PARISH, J. H. \& KIRBY, K. S. (1966). Reagents which reduce interactions between ribosomal RNA and rapidly labelled RNA from rat liver. Biochemica et biophysica acta 129, 554-562.

RAMSAY, W. S. \& DWorkin, M. (1968). Microcyst germination in Myxococcus xanthus. Journal of Bacteriology 95, 2249-2257.

RAmSAY, W. S. \& DWORKIN, M. (1970). Stable messenger ribonucleic acid and germination of Myxococcus xanthus microcysts. Journal of Bacteriology ror, 531-540.

Rosenberg, E., Katarski, M. \& GotTlieb, P. (1967). Deoxyribonucleic acid synthesis during exponential growth and microcyst formation in Myxococcus xanthus. Journal of Bacteriology 93, 1402-1 408.

SADLER, W. \& DWORKIN, M. (1966). Induction of cellular morphogenesis in Myxococcus xanthus. II. Macromolecular synthesis and mechanism of inducer action. Journal of Bacteriology 91, 1520-1 525.

Sakakibara, Y., Tanooka, H. \& Terano, H. (1970). Defined conditions for DNA extraction from Bacillus subtilis spores. Biochimica et biophysica acta, 199, 549-550.

UCHida, T. \& Egami, F. (1967). Ribonuclease $\mathrm{T}_{1}$ from takadiastase. In Methods in Enzymology, vol. XII A, pp. 228-239. Edited by L. Grossman and K. Moldave. New York and London: Academic Press.

Zusman, D., Gottlieb, P. \& RosenberG, E. (I97r). Division cycle of Myxococcus xanthus. III. Kinetics of cell growth and protein synthesis. Journal of Bacteriology 105, 81 I-819.

Zusman, D. \& Rosenberg, E. (I970). DNA cycle and Myxococcus xanthus. Journal of Molecular Biology 49, 609-6I9.

Zusman, D. \& RosenberG, E. (I971). Division cycle of Myxococcus xanthus. II. Kinetics of stable and unstable ribonucleic acid synthesis. Journal of Bacteriology 105, 801-810.

27

M I C 75 